\title{
Detection of pH and Urea with an Extended Gate Field-Effect Transistor-Based Microsensor
}

\author{
İpek Avc1 ${ }^{1}$, Merve Oğuz ${ }^{2}$, Mustafa Şen ${ }^{3 *}$ \\ ${ }^{1}$ Izmir Katip Celebi University, Graduate School of Natural and Applied Sciences, Biomedical Engineering Graduate Program, Izmir, Turkey, \\ (ORCID: 0000-0003-4782-4421), ipekavci35@gmail.com \\ ${ }^{2}$ Izmir Katip Celebi University, Graduate School of Natural and Applied Sciences, Biomedical Engineering Graduate Program, Izmir, Turkey, \\ (ORCID: 0000-0002-7999-0005), merveoguz345@gmail.com \\ 3* Izmir Katip Celebi University, Faculty of Engineering and Architecture, Department of Biomedical Engineering, İzmir, Turkey \\ (ORCID: 0000-0002-2421-9184), mustafa.sen@ikc.edu.tr
}

(First received 19 October 2021 and in final form 7 December 2021)

(DOI: 10.31590/ejosat.1012049)

ATIF/REFERENCE: Avcı, İ., Oğuz, M. \& Şen, M. (2021). Detection of pH and Urea with an Extended Gate Field-Effect TransistorBased Microsensor. European Journal of Science and Technology, (31), 874-880.

\begin{abstract}
Extended gate field-effect transistor-based (EGFET) microsensors have been developed for highly sensitive detection of $\mathrm{pH}$ and urea. EGFET was made by integrating with a microelectrode. Briefly, the EGFET-based $\mathrm{pH}$ microsensor was developed by modifying the surface of a microelectrode with polypyrrole (PPy) via electropolymerization and integrating it with a small, simple, and inexpensive metal oxide semiconductor field-effect transistor (MOSFET). As for the EGFET-based urea microsensor, urease enzyme was immobilized in PPy. The measurements of $\mathrm{pH}$ and urea were made in solutions at different $\mathrm{pH}$ values and the urea concentrations, respectively. The results showed that the $\mathrm{pH}$ microsensor had a very good sensitivity of $67 \mathrm{mV} / \mathrm{pH}$ in a pH range of 5-12. Similarly, the EGFET-based urea microsensor showed a linear response range of $10^{-9}$ to $10^{-5} \mathrm{M}$ urea with sensitivities of $35.5 \mathrm{mV} / \mathrm{dec}$ ade urea and 10 $\mu \mathrm{A} /$ decade urea. The reported EGFET-based $\mathrm{pH}$ and urea microsensors have great potential for use in the biomedical field, especially in applications where local analysis is required.
\end{abstract}

Keywords: EGFET, pH, urea, urease, polypyrrole, electropolymerization, microsensor

\section{Genişletilmiş Kapı Alan Etkili Transistör Tabanlı Mikrosensör ile pH ve Üre Tespiti}

$\ddot{\mathbf{O} z}$

pH ve ürenin yüksek hassasiyette tespiti için genişletilmiş kapı alan-etkili transistör tabanlı (EGFET) mikrosensörler geliştirilmiştir. EGFET, bir mikroelektrot ile entegre edilerek oluşturulmuştur. Kısaca, EGFET-tabanlı pH mikrosensörü, mikroelektrot yüzeyine elektropolimerizasyon yoluyla polipirol (PPy) modifiye edilerek ve buna küçük, basit ve ucuz yarı iletken metal oksit alan etkili transistör (MOSFET) entegre edilmesiyle geliştirilmiştir. EGFET-tabanlı üre mikrosensöründe ise, üreaz enzimi PPy içerisine mobilize edilmiştir. $\mathrm{pH}$ ve üre ölçümleri sırasıyla farklı pH değerlerine ve üre konsantrasyonlarına sahip solüsyonlarla yapılmıştır. Sonuçlar pH mikrosensörünün pH 5-12 aralığında $67 \mathrm{mV} / \mathrm{pH}$ gibi çok iyi bir hassasiyete sahip olduğunu göstermiştir. Benzer şekilde, EGFET-tabanlı üre mikrosensörü, $35.5 \mathrm{mV} /$ decade üre ve $10 \mu \mathrm{A} /$ decade üre hassasiyetleriyle birlikte $10^{-9}-10^{-5} \mathrm{M}$ üre aralığında doğrusal bir yanıt gösterdi. Bildirilen EGFET pH ve üre mikrosensörleri, biyomedikal alanda, özellikle yerel analizin gerekli olduğu uygulamalarda kullanım için büyük potansiyele sahiptir.

Anahtar Kelimeler: EGFET, pH, üre, üreaz, polipirol, elektropolimerizasyonu, mikrosensör 


\section{Introduction}

$\mathrm{pH}$ defined as a logarithmic measure of hydrogen ion concentration is a basic analytical measure of the mechanism of chemical or biological reactions (Li et al., 2020, Şen et. al., 2016). Proper measurement and control of $\mathrm{pH}$ is essential for many industrial applications and living organisms due to its relevance to many chemical and biochemical processes (Vonau \& Guth, 2006). For example, urea, acetylcholine, and L-arginine can be detected by sensing $\mathrm{pH}$ change (Fenoy et al., 2020). Among them, urea has taken great attention from researchers, and for detection of urea, many techniques have been improved. As a result of protein metabolism, ammonia is converted to urea in the kidneys and liver. Since urea is a product of protein metabolism, balancing it in the human body is important for renal health. The urea level is considered an important marker for monitoring kidney functions. Measuring urea for medical diagnosis can show malnutrition, renal functioning, increased catabolism of proteins, high protein diet, pregnancy, dehydration, inhibition in urinary system, shock, and stress (Jakhar et al., 2018). The urea level in a healthy human should be in the range of $8-20 \mathrm{mg} / \mathrm{dL}$ (Ahuja et al., 2008).

Ion sensitive field-effect transistor (ISFET) is a special type of metal oxide semiconductor field-effect transistor (MOSFET) and used for measuring ion concentration. The metal gate of MOSFET is replaced by an ion-sensitive membrane, electrolyte solution, and a reference electrode in ISFET. The working principle of ISFET is based on change in current caused by a change in ion concentration. The advantages of ISFET are low power consumption, low cost, ease of operation, small size, fast response time, significant durability, easy storage, and lower temperature dependence (Avolio et al., 2020). In addition, ISFETs are highly sensitive, and can potentially be miniaturized (Ghoneim et al., 2019). Despite the various advantages, ISFETs suffer from the need for reference electrodes, complex gate encapsulation procedures, and costly cleanroom processes (Mokhtarifar et al., 2019). As an alternative, extended gate fieldeffect transistor-based (EGFET) sensors have been intensively studied for chemical sensing including $\mathrm{pH}$ measurement (Pan et al., 2003). Unlike ISFET the sensing membrane of an EGFETbased sensor is placed away from the field-effect transistor (FET) device which has no direct contact with the chemical environment. The working principle of an EGFET-based sensor relies on the change in the response of the sensing membrane to varying concentrations of analytes. For example, the change in the conductivity of a sensing membrane such as polypyrrole (PPy) at different $\mathrm{pHs}$ modulates the potential applied through the gate and thus changes the electric current flowing between drain and source electrodes (Ghoneim et al., 2019). Physically separating the sensing membrane and protecting the gate region ensures that the activity of the target analyte makes an additional chemical contribution to the threshold voltage (Pullano et al., 2018). EGFET-based sensors possess advantages such as high transconductance, improved threshold voltage shift, stability, improved responsiveness, low noise, low mass production cost, and being disposable (Pullano et al., 2019).

In recent years, popularity of conducting polymers are increasing in the field of sensors due to their low cost, robustness, and versatility (Avolio et al., 2020). Conductive polymers offer a practical matrix, especially for the encapsulation of enzymes in a one-step procedure (Ahuja et al., 2008). Entrapment of enzymes in conducting polymers not only increases the lifetime of the enzyme but also reduces the cost of measurement. Entrapment of enzymes in conducting polymers permits the localization of biologically active molecules on electrodes of different geometry/size and increases the possibility of precisely polymer coating over conductive microsurfaces with complex geometry (Ahuja et al., 2008; Cosnier \& biotechnology, 2000). Entrapment of enzymes in conductive polymers can be achieved via chemical or electrochemical polymerization. Electropolymerization is often preferred due to its advantages such as better controllability of film thickness and morphology. The electropolymerization process takes place on the electrode surface by anodic oxidation of the corresponding monomer in the electrolyte solution.

PPy is a biocompatible conducting polymer and can be used as a sensing membrane in $\mathrm{pH}$ sensors. It has high chemical stability, easy oxidation, low monomer cost, high biocompatibility, very good thermal, mechanical and electrical properties (Vandana Bisht et al., 2005; Pandey et al., 2018). In addition, pyrrole (Py) monomer has the advantage of being easily oxidized, water-soluble, and commercially available (Sadki et al., 2000). There are many studies in the literature where PPy was applied to $\mathrm{pH}$ sensing. For example, Lakard et al. developed a potentiometric $\mathrm{pH}$ sensor based on PPy. The sensor had a quasilinear response between $\mathrm{pH} 2$ and 11 with a $\mathrm{pH}$ sensitivity of -51 $\mathrm{mV} / \mathrm{pH}$ (Lakard et al., 2007). In a similar study, the effect of PPy film thickness and scan rate on $\mathrm{pH}$ sensitivity was measured and the highest response slope was reported to be $53.0 \mathrm{mV} / \mathrm{pH}$ at a scan rate of $25 \mathrm{mV} / \mathrm{s}$ (Mo et al., 2003). In another work, Naser et al. designed an electrochemical flow cell $\mathrm{pH}$ sensor for aqueous solutions based on EGFET. Two different sensitivities were obtained on days 1 and 15 in the $\mathrm{pH}$ range of 8.00 to 10.80 . The sensitivity on day $1(52.31 \mathrm{mV} / \mathrm{pH})$ decreased to $42.65 \mathrm{mV} / \mathrm{pH}$ on day 15 (Mokhtarifar et al., 2019). PPy has also been applied for the electrochemical detection of urea. For example, Rajesh et al. designed a potentiometric urea biosensor by electrochemically preparing a conducting copolymer poly( $N$-3-aminopropyl pyrrole-co-pyrrole) (PAPCP) film onto an indium-tin-oxide (ITO) coated glass plate. The urease enzyme was covalently immobilized on the prepared polymer. In the study, both $\mathrm{pH}$ and urea measurements were carried out. The $\mathrm{pH}$ and urea sensitivity of the sensor were $47 \mathrm{mV} / \mathrm{pH}$ and $27.5 \mathrm{mV} /$ decade urea, respectively (V Bisht et al., 2005). In a different study, a potentiometric urea biosensor was developed by electropolymerization of PPy, p-toluene sulphonic acid and BSA onto an ITO coated glass plate. The urease enzyme was covalently linked to the prepared conducting PPy. The sensor showed a linear response in the range of $6.6 \times 10^{-6}$ to $7.5 \times 10^{-4} \mathrm{M}$ with a sensitivity of $17.3 \mathrm{mV} /$ decade (Ahuja et al., 2008).

Here, a novel EGFET-based $\mathrm{pH}$ and urea microsensor was developed. Briefly, the microsensors were constructed by integrating PPy-modified microelectrode with a small, simple and inexpensive MOSFET. First, PPy was electrochemically deposited on a gold microdisk electrode as a sensing membrane for $\mathrm{pH}$ measurement. The electrochemical deposition of PPy was carried out in galvanostatic mode. After optimizing the deposition time, the sensor was tested in phosphate buffered saline (PBS) at various pHs. Next, urease enzyme was entrapped in PPy to construct an EGFET-based urea microsensor, which is new to the best of our knowledge. Results showed that the EGFET-based $\mathrm{pH}$ and urea microsensors detected $\mathrm{pH}$ and urea successfully with good sensitivity. The reported microsensors have great potential 
for use in the biomedical field, especially in applications where local analysis is required.

\section{Materials and Methods}

\subsection{Materials}

Phosphate buffered saline (PBS) (Sigma-Aldrich, USA), sodium hydroxide $(\mathrm{NaOH})$ (Sigma-Aldrich, USA), hydrogen chloride ( $\mathrm{HCl}$ ) (Sigma-Aldrich, USA), Py (Sigma-Aldrich, USA), lithium perchlorate $\left(\mathrm{LiClO}_{4}\right)$ (Sigma-Aldrich, USA), perchloric acid (HClO4) (Supelco, USA), urea (Sigma-Aldrich, USA), urease (Sigma-Aldrich, USA), silver paste (Sigma-Aldrich, USA), n-type MOSFET (IRFZ44N, International Rectifier, USA)

\subsection{Microchip fabrication}

A glass slide was spin coated with S1818 positive photoresist at $2000 \mathrm{rpm}$ for $30 \mathrm{sec}$. After prebaking, the photoresist was patterned via contact lithography. The exposed areas of the photoresist were removed using a developer solution (CD26, Microchem, USA). Titanium and gold films were sputtered on the glass slide with a patterned photoresist. Lastly, the remaining photoresist was removed using acetone to define the gold ( $\mathrm{Au}$ ) patterns of the microchip (Şen et al., 2013; Şen et al., 2012; Şen et al., 2014). Next, SU-8 photoresist was spin coated, prebaked and patterned using photolithography. After post baking, the unexposed regions were removed to define the diameter of the microdisk electrode $(40 \mu \mathrm{m})$. Prior to use, the SU-8 layer was hard-baked at $180{ }^{\circ} \mathrm{C}$ for $30 \mathrm{~min}$. A silver (Ag) electrode was printed on the microchip as a reference electrode using Ag paste.

\subsection{PPy electropolymerization and $\mathrm{pH}$ detection with an EGFET-based pH microsensor}

PPy solution was prepared using $0.2 \mathrm{M}$ Py $0.2 \mathrm{M}$ lithium perchlorate $\left(\mathrm{LiClO}_{4}\right)$ and $0.1 \mathrm{M}$ perchloric acid $\left(\mathrm{HClO}_{4}\right)$. A twoelectrode electrochemical cell was used for electropolymerization. Electropolymerization of the PPy solution was carried out in galvanostatic mode by applying a current of 0.1 $\mu \mathrm{A}$ to the working electrode (gold electrode) for different time intervals $(1,3,4,5$ and $10 \mathrm{~min})$ by potentiostat/galvanostat (PGSTAT204, Metrohm, Switzerland). The measurement capacity and characterization of the EGFET-based $\mathrm{pH}$ microsensors were performed in PBS solutions at varying $\mathrm{pH}$ values using a FET analysis unit (B2901A Precision Source/Measure Unit) (Aykaç et. al., 2021). While the source and the drain of the n-type MOSFET were connected to the source and drain inputs of the FET analysis unit, the gate is connected to the EGFET-based $\mathrm{pH}$ microsensor. In order to make the measurement more sensitive and stable, $\mathrm{pH}$ measurements were carried out using an Ag electrode printed on the microchip. PBS solutions at different $\mathrm{pH}(5.53$ - 7.08 - 7.96 - 8.57 - 9.82 - 12.07) were used to determine the $\mathrm{pH}$ sensitivity of the EGFET $\mathrm{pH}$ microsensor. IDs$\mathrm{V}_{\mathrm{GS}}$ curves were obtained by scanning the gate potential from 0 to $+2 \mathrm{~V}$ while applying a constant potential of $+0.5 \mathrm{~V}$ between the source and the drain electrodes. The effect of different time intervals on $\mathrm{pH}$ sensitivity was calculated.

\subsection{PPy/urease electropolymerization and urea detection with an EGFET-based urea microsensor}

A Py-urease solution was prepared by dissolving $4 \mathrm{mg}$ of urease in $75 \mu \mathrm{l}$ of PPy solution. Electropolymerization of the Pyurease solution was carried out in galvanostatic mode by applying a current of $0.1 \mu \mathrm{A}$ for 180 seconds by potentiostat (Aydin \& Şen, 2017). The sensor was tested in deionized water containing varying concentration of urea $\left(10^{-9} \mathrm{~mol} / \mathrm{L}, 10^{-8} \mathrm{~mol} / \mathrm{L}, 10^{-7} \mathrm{~mol} / \mathrm{L}\right.$, $10^{-6} \mathrm{~mol} / \mathrm{L}, 10^{-5} \mathrm{~mol} / \mathrm{L} 10^{-4} \mathrm{~mol} / \mathrm{L}, 10^{-3} \mathrm{~mol} / \mathrm{L}, 10^{-2} \mathrm{~mol} / \mathrm{L}$, and $10^{-}$ $\left.{ }^{1} \mathrm{~mol} / \mathrm{L}\right)$. Both $\mathrm{I}_{\mathrm{DS}}-\mathrm{V}_{\mathrm{GS}}$ and $\mathrm{I}_{\mathrm{DS}}-\mathrm{V}_{\mathrm{DS}}$ curves were obtained. In the case of $\mathrm{I}_{\mathrm{DS}}-\mathrm{V}_{\mathrm{GS}}$, the potential applied to the gate was scanned from 0 to $+2 \mathrm{~V}$, while a constant potential of $+0.5 \mathrm{~V}$ was applied between the source and the drain electrodes. As for the $I_{D S}-V_{D S}$ curves, the potential applied to the drain was scanned from 0 to + $2 \mathrm{~V}$, while a constant potential of $+0.5 \mathrm{~V}$ was applied between the gate and the source electrodes.
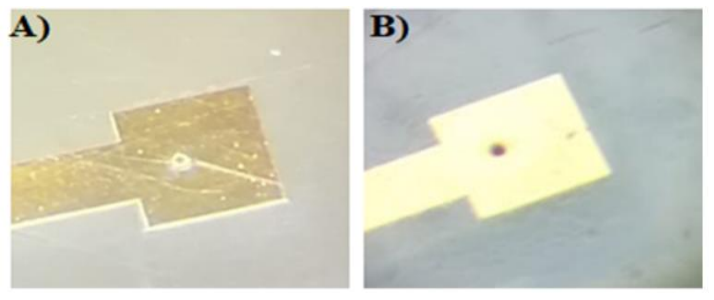

Figure 1. Optical images of an Au microelectrode before (A) and after electropolymerization of PPy/urease (B).

\section{Results and Discussion}

PPy is a biocompatible conducting polymer and can be used as a sensing membrane in $\mathrm{pH}$ sensors. Basically, PPy was electrochemically deposited on an $\mathrm{Au}$ microelectrode for high sensitive detection of $\mathrm{pH}$ which was then applied for the detection of urea. Microelectrodes have several advantages over traditional macroscale electrodes, e.g. fast response, high current density, high signal-to-noise ratio, low I-R drop, small double layer capacitance.

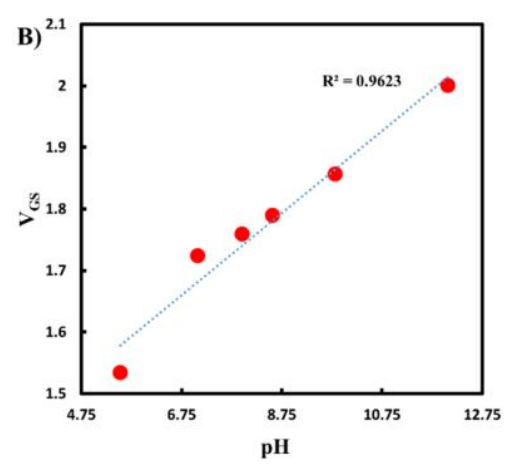

Figure 2. $I_{D S^{-}} V_{G S}$ curves obtained at varying $p H$ values $(A)$ and a calibration curve based on a constant $I_{D S}$. 
Microelectrodes are considered powerful tools for in vivo or on-site measurements in various fields such as physiology, microbial ecology, medicine, neuroscience, and environmental monitoring. After the PPy deposition on an Au microelectrode, the success of the process was first checked with a microscope (Top Ring Led Illuminated Stereo Microscope). As can be seen in Figure 1, the color of Au microelectrode changed from orangeyellow to black, confirming the successful coating of PPy.

EGFET-based $\mathrm{pH}$ microsensors use chemical protonation and deprotonation reactions causing a potential difference between the solution and the extended gate of the transistor. The EGFET-based $\mathrm{pH}$ microsensor was connected to an n-type MOSFET and IDS$\mathrm{V}_{\mathrm{GS}}$ curves were obtained in PBS solutions at different $\mathrm{pH}$ values. As shown in Figure 2A, the obtained $\mathrm{I}_{\mathrm{DS}}-\mathrm{V}_{\mathrm{GS}}$ curves changed with changing $\mathrm{pH}$ of the solution being measured. The change in the conductivity of the semiconductor PPy at different $\mathrm{pH}$ has modulated the potential applied to the channel between the source and the drain in the MOSFET. This situation resulted in different $\mathrm{I}_{\mathrm{DS}}-\mathrm{V}_{\mathrm{GS}}$ curves at different $\mathrm{pH}$ values. According to the results, EGFET-based $\mathrm{pH}$ microsensor successfully detected $\mathrm{pH}$ in a relatively wide range of 5 to 12 with a $\mathrm{pH}$ sensitivity of 67 $\mathrm{mV} / \mathrm{pH}$. A calibration curve was also obtained based on $\mathrm{V}_{\mathrm{GS}}$ at $\mathrm{I}_{\mathrm{DS}}$ $=3 \mu \mathrm{A}$ with an $\mathrm{R}^{2}$ value of 0.99 , clearly showing that the relationship between $\mathrm{pH}$ and voltage values was linear (Figure 2B). The thickness of the PPy coating can greatly affect the sensitivity of the sensor.

In order to see the effect of electropolymerization time on the sensitivity, $0.1 \mu \mathrm{A}$ current was applied to the working electrode for 1, 3, 4, 5 and 10 min in galvanostatic mode. It is known that the thickness of PPy can be roughly controlled by controlling the electropolymerization time (Adeloju et al., 1996). Long or short PPy deposition times greatly reduced the $\mathrm{pH}$ sensitivity of EGFET-based $\mathrm{pH}$ microsensor. For example, electrochemical deposition of PPy for 1 and 10 min resulted in $\mathrm{pH}$ sensitivities of 29 and $27 \mathrm{mV} / \mathrm{pH}$, respectively. According to the results, $4 \mathrm{~min}$ deposition time yielded the highest sensitivity. In addition, incubating for $40 \mathrm{~min}$ at room temperature improved the sensitivity by $27 \mathrm{mV} / \mathrm{pH}$. In Table 1 , the performance of the EGFET-based $\mathrm{pH}$ microsensor is compared with some recent reports in which $\mathrm{pH}$ sensitivity was determined electrochemically with various modified electrodes. The PPy-modified EGFETbased $\mathrm{pH}$ microsensor seemed to outperform most of these electrodes in terms of both $\mathrm{pH}$ sensitivity and linear range. In addition to $\mathrm{pH}$ sensing, the polymer can also be applied for the enzymatic detection of urea. Basically, urease catalyzes the conversion of urea and releases hydroxide ions, which in turn changes the local pH Eq.(1) (Syu et al., 2009). The local $\mathrm{pH}$ change can be easily associated with the level of urea in the environment.

$$
\mathrm{NH}_{2} \mathrm{CONH}_{2}+3 \mathrm{H}_{2} \mathrm{O}+\mathrm{H}^{+} \stackrel{\text { (urease) }}{\longrightarrow} \mathrm{HCO}_{3}^{-}+\mathrm{OH}^{-}+2 \mathrm{NH}_{4}^{+}
$$

Equation 1: Chemical equation of reaction between urea and urease (Syu et al., 2009)

The adopted strategy allowed the entrapment of the enzyme with PPy in a single step. The EGFET-based urea microsensor was tested in deionized water containing different concentration of urea ranging from $10^{-1} \mathrm{~mol} / \mathrm{L}$ to $10^{-9} \mathrm{~mol} / \mathrm{L}$. As can be seen in Figure $3 \mathrm{~A}_{\mathrm{i}}$, the $\mathrm{I}_{\mathrm{DS}}-\mathrm{V}_{\mathrm{GS}}$ curves differed depending on the urea concentration of the solution being measured. The gate voltage of the MOSFET is affected by the potential of the EGFET and the potential of the sensing film may appear as the potential source. Since urease changes the local $\mathrm{pH}$ in the presence of urea, the working principle of EGFET-based urea microsensor is the same as the EGFET-based $\mathrm{pH}$ microsensor. $\mathrm{V}_{\mathrm{GS}}$ shifts to a more positive direction with increasing urea concentration, which is reasonable as the ammonia produced by the enzyme has a $\mathrm{pH}$ causing the local $\mathrm{pH}$ to increase. The calibration curve demonstrating the relationship between $\mathrm{V}_{\mathrm{GS}}$ and -log [urea] has a $\mathrm{R}^{2}$ value of 98.63 (Figure $3 \mathrm{~A}_{\mathrm{ii}}$ ). Although the sensor gave very good linear response between $10^{-9} \mathrm{~mol} / \mathrm{L}$ and $10^{-5} \mathrm{~mol} / \mathrm{L}$ with a sensitivity of 35.5 $\mathrm{mV} /$ decade, the same was not true for larger concentrations. This may be because the enzyme reaches saturation after a certain level of urea concentration. In addition to $\mathrm{I}_{\mathrm{DS}}-\mathrm{V}_{\mathrm{GS}}$ curves, $\mathrm{I}_{\mathrm{DS}}-\mathrm{V}_{\mathrm{DS}}$ curves were also obtained. 

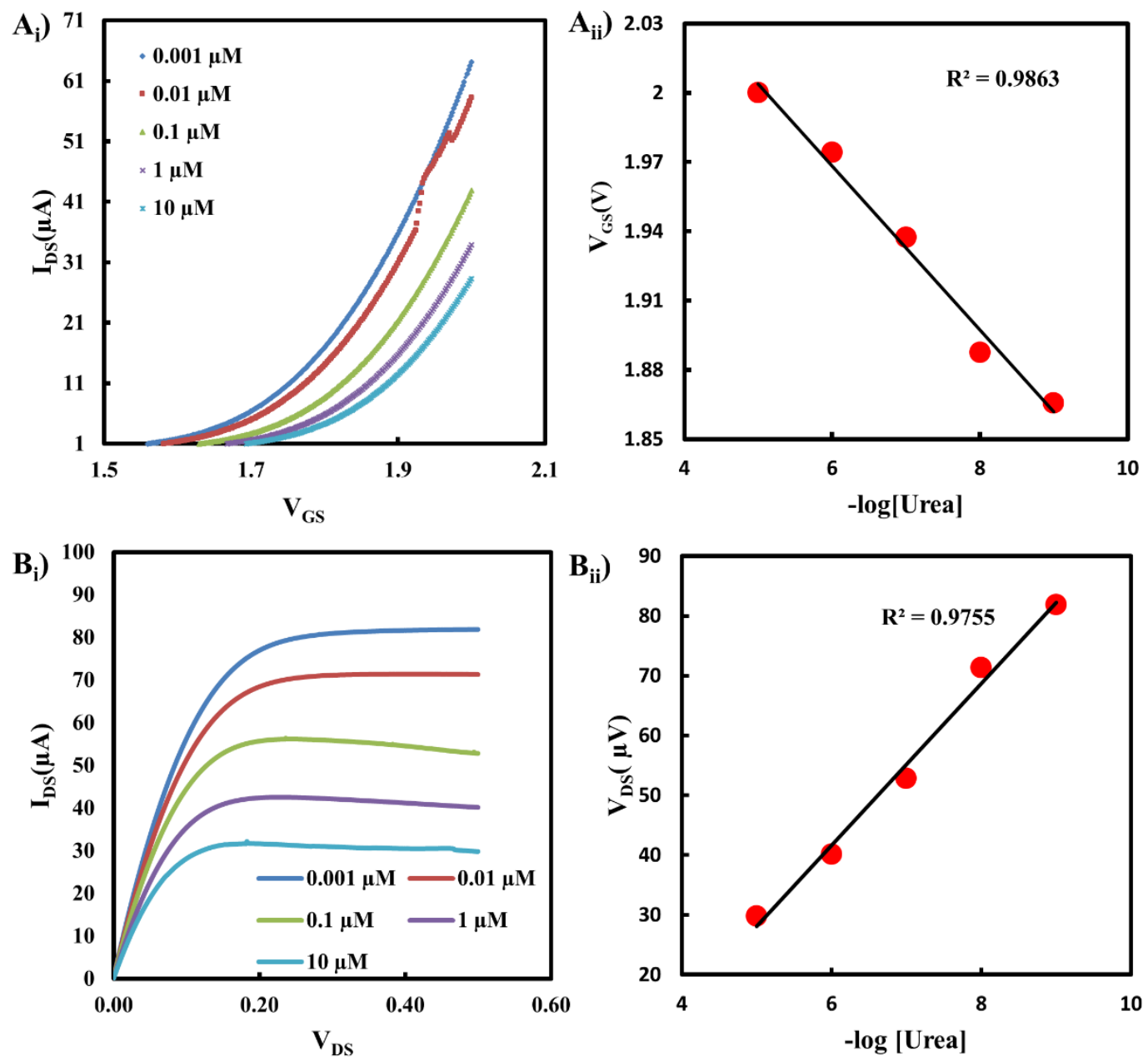

Figure 3. $I_{D S^{-}} V_{G S}\left(A_{i}\right)$ and $I_{D S} V_{D S}\left(B_{i}\right)$ curves obtained at varying urea concentrations along with respective calibration curves $\left(A_{i i}\right.$, $B_{i i)}$

The response of the EGFET-based urea microsensor examined in the saturation regime of the MOSFET. Figure $3 \mathrm{~B}_{\mathrm{i}}$ shows that the $\mathrm{I}_{\mathrm{DS}}-\mathrm{V}_{\mathrm{DS}}$ characteristics of the sensor changed accordingly with varying concentration of urea. Basically, the conductivity of PPy dropped at high $\mathrm{pH}$ caused by the enzymatic reaction of urease and thus $\mathrm{I}_{\mathrm{DS}}$ got reduced with increasing urea concentration. It can be clearly seen in Figure $3 B_{i}$ that the $I_{D S}$ values became nearly constant after a certain $V_{D S}$ in all test solutions at a fixed $\mathrm{V}_{\mathrm{GS}}=+0.5 \mathrm{~V}$. A calibration curve was obtained the same as before. The relationship between IDs and $\log$ [urea] was linear with an $\mathrm{R}^{2}$ value of 97.55 (Figure $3 \mathrm{~B}_{\mathrm{ii}}$ ). The sensitivity of the sensor was calculated to be $10 \mu \mathrm{A} /$ decade. In Table 2, the performance of the EGFET-based urea microsensor was compared to the analytical performance of different enzymatic urea sensors. The present urea microsensor seemed to have a good linear range and sensitivity. EGFET-based microsensors can be used in bioanalytical applications with advantages such as miniaturization, convenient integration into different micro-systems, stability to environmental changes such as light and temperature, high conductivity, and sensitivity.

\section{Conclusions and Recommendations}

The use of EGFET-based microsensors for $\mathrm{pH}$ and urea detection has been successfully demonstrated. PPy was preferred as a sensing membrane because of its $\mathrm{pH}$ sensitivity. Since the thickness of PPy greatly affects the $\mathrm{pH}$ sensitivity, polymer deposition time was used to control the thickness and the optimum deposition time was found to be 4 min. Incubation at room temperature also improved and stabilized the response of the sensor. The EGFET-based $\mathrm{pH}$ microsensor had a good linear range ( $\mathrm{pH} 5-12)$ and $\mathrm{pH}$ sensitivity $(67 \mathrm{mV} / \mathrm{pH})$. Using the same approach as the EGFET-based $\mathrm{pH}$ microsensor, EGFET-based urea microbiosensor was fabricated quickly and easily in a single step, where the enzyme urease was encapsulated in PPy during electrochemical deposition. Urea microbiosensor gave a response similar to the $\mathrm{pH}$ microsensor. The sensor exhibited a linear response in the urea concentration range of $10^{-9} \mathrm{M}$ to $10^{-5} \mathrm{M}$ with a sensitivity of $35.5 \mathrm{mV} /$ decade. In the light of the obtained results, it can be said that EGFET-based $\mathrm{pH}$ and urea microsensors have great potential to be used for bioanalysis, especially in applications where local analysis is required. 
Table 1. Comparison of the analytical performance of different modified electrodes for pH measurements

\begin{tabular}{|c|c|c|c|c|}
\hline InZnxOy-based EGFET & 56.29 & $2-12$ & 0.999 & (Singh et al., 2019) \\
\hline AlN-gate ISFET based $\mathrm{pH}$ sensor & $\sim 33$ & $4-10$ & 0.98145 & (Sinha et al., 2019) \\
\hline Graphene oxide-modified carbon electrodes/pH & 51 & $2-10$ & 0.9912 & (Neupane et al., 2021) \\
\hline MWCNT/PANI-modified SPCE & 20.63 & $2-11$ & 0.99089 & (Bao et al., 2019) \\
\hline
\end{tabular}

Table2. Comparison of analytical performance of different enzymatic urea sensors measurements

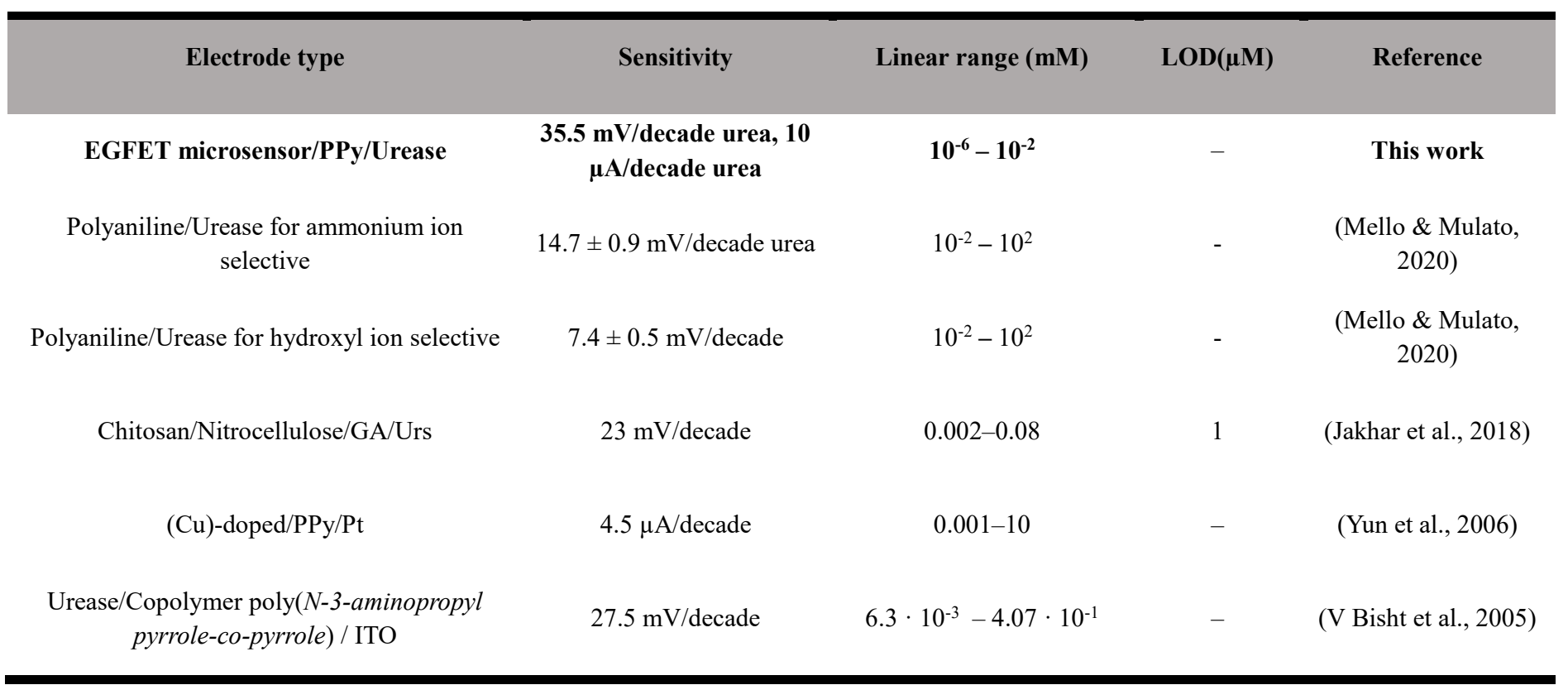

\section{Acknowledge}

This research was supported by the scientific research projects coordination unit of Izmir Katip Celebi University (Project No: 2021-GAP-MÜMF-0055).

\section{References}

Adeloju, S. B., Shaw, S. J., \& Wallace, G. G. (1996). Poly-based amperometric flow injection biosensor for urea. Analytica Chimica Acta, 323(1-3), 107-113.

Ahuja, T., Mir, I. A., \& Kumar, D. (2008). Potentiometric urea biosensor based on BSA embedded surface modified polypyrrole film. Sensors and Actuators B: Chemical, 134(1), 140-145.
Avolio, R., Grozdanov, A., Avella, M., Barton, J., Cocca, M., De Falco, F., .. \& Magni, P. (2020). Review of pH sensing materials from macro-to nano-scale: Recent developments and examples of seawater applications. Critical Reviews in Environmental Science and Technology, 1-43.

Aydin, V. K., \& Şen, M. (2017). A facile method for fabricating carbon fiber-based gold ultramicroelectrodes with different shapes using flame etching and electrochemical deposition. Journal of Electroanalytical Chemistry, 799, 525-530.

Aykaç, A., Tunç, I. D., Guneş, F., Erol, M., \& Şen, M. (2021). Sensitive $\mathrm{pH}$ measurement using EGFET microsensor based on $\mathrm{ZnO}$ nanowire functionalized carbon-fibers. Nanotechnology, 32, 365501.

Bao, Q., Yang, Z., Song, Y., Fan, M., Pan, P., Liu, J., ... \& Wei, J. (2019). Printed flexible bifunctional electrochemical urea-pH sensor based on multiwalled carbon nanotube/polyaniline 
electronic ink. Journal of Materials Science: Materials in Electronics, 30(2), 1751-1759.

Bisht, V., Takashima, W., \& Kaneto, K. (2005). An amperometric urea biosensor based on covalent immobilization of urease onto an electrochemically prepared copolymer poly (N-3aminopropyl pyrrole-co-pyrrole) film. Biomaterials, 26(17), 3683-3690.

Bisht, V., Takashima, W., \& Kaneto, K. (2005). Development of a potentiometric urea biosensor based on copolymer poly $(\mathrm{N}$ 3-aminopropyl pyrrole-co-pyrrole) film. Reactive and Functional Polymers, 62(1), 51-59.

Cosnier, S. (2000). Biosensors based on immobilization of biomolecules by electrogenerated polymer films. Applied biochemistry and biotechnology, 89(2), 127-138.

Fenoy, G. E., Marmisollé, W. A., Azzaroni, O., \& Knoll, W. (2020). Acetylcholine biosensor based on the electrochemical functionalization of graphene field-effect transistors. Biosensors and Bioelectronics, 148, 111796.

Ghoneim, M. T., Nguyen, A., Dereje, N., Huang, J., Moore, G. C., Murzynowski, P. J., \& Dagdeviren, C. (2019). Recent progress in electrochemical $\mathrm{pH}$-sensing materials and configurations for biomedical applications. Chemical reviews, 119(8), 5248-5297.

Jakhar, S., \& Pundir, C. S. (2018). Preparation, characterization and application of urease nanoparticles for construction of an improved potentiometric urea biosensor. Biosensors and Bioelectronics, 100, 242-250.

Lakard, B., Segut, O., Lakard, S., Herlem, G., \& Gharbi, T. (2007). Potentiometric miniaturized $\mathrm{pH}$ sensors based on polypyrrole films. Sensors and Actuators B: Chemical, 122(1), 101-108.

Li, Y., Mao, Y., Xiao, C., Xu, X., \& Li, X. (2020). Flexible pH sensor based on a conductive PANI membrane for $\mathrm{pH}$ monitoring. RSC Advances, 10(1), 21-28.

Mello, H. J. N. P. D., \& Mulato, M. (2020). Enzymatically functionalized polyaniline thin films produced with one-step electrochemical immobilization and its application in glucose and urea potentiometric biosensors. Biomedical microdevices, 22(1), 1-9.

Mo, X., Wang, J., Wang, Z., \& Wang, S. (2003). Potentiometric $\mathrm{pH}$ responses of fibrillar polypyrrole modified electrodes. Sensors and Actuators B: Chemical, 96(3), 533536.

Mokhtarifar, N., Goldschmidtboeing, F., \& Woias, P. (2019). ITO/glass as extended-gate of FET: A low-cost method for differential $\mathrm{pH}$-sensing in alkaline solutions. Journal of The Electrochemical Society, 166(12), B896.

Neupane, S., Subedi, V., Thapa, K. K., Yadav, R. J., Nakarmi, K. B., Gupta, D. K., \& Yadav, A. P. (2021). An alternative pH sensor: graphene oxide-based electrochemical sensor. Emergent Materials, 1-9.

Pan, C. W., Chou, J. C., Kao, I. K., Sun, T. P., \& Hsiung, S. K. (2003). Using polypyrrole as the contrast $\mathrm{pH}$ detector to fabricate a whole solid-state $\mathrm{pH}$ sensing device. IEEE sensors journal, 3(2), 164-170.

Pandey, A. K., Pandey, P. C., Agrawal, N. R., \& Das, I. (2018). Synthesis and characterization of dendritic polypyrrole silver nanocomposite and its application as a new urea biosensor. Journal of Applied Polymer Science, 135(3), 45705.
Prissanaroon-Ouajai, W., Pigram, P. J., Jones, R., \& Sirivat, A. (2009). A sensitive and highly stable polypyrrole-based $\mathrm{pH}$ sensor with hydroquinone monosulfonate and oxalate codoping. Sensors and Actuators B: Chemical, 138(2), 504-511.

Pruna, R., Palacio, F., Fuentes, I., Viñas, C., Teixidor, F., \& López, M. (2018). A Novel Transparent $\mathrm{pH}$ Sensor Based on a Nanostructured ITO Electrode Coated with [3, 3'-Co (1, 2C2B9H11) 2]-Doped Poly (pyrrole). In Multidisciplinary Digital Publishing Institute Proceedings (Vol. 2, No. 13, p. 869).

Pullano, S. A., Critello, C. D., Mahbub, I., Tasneem, N. T., Shamsir, S., Islam, S. K., ... \& Fiorillo, A. S. (2018). EGFETbased sensors for bioanalytical applications: A review. Sensors, 18(11), 4042.

Pullano, S. A., Tasneem, N. T., Mahbub, I., Shamsir, S., Greco, M., Islam, S. K., \& Fiorillo, A. S. (2019). Deep submicron EGFET based on transistor association technique for chemical sensing. Sensors, 19(5), 1063.

Sadki, S., Schottland, P., Brodie, N., \& Sabouraud, G. (2000). The mechanisms of pyrrole electropolymerization. Chemical Society Reviews, 29(5), 283-293.

Singh, K., Her, J. L., Lou, B. S., Pang, S. T., \& Pan, T. M. (2019). An extended-gate FET-based $\mathrm{pH}$ sensor with an InZn x O y membrane fabricated on a flexible polyimide substrate at room temperature. IEEE Electron Device Letters, 40(5), 804807.

Sinha, S., Mukhiya, R., Sharma, R., Khanna, P. K., \& Khanna, V. K. (2019). Fabrication, characterization and electrochemical simulation of AIN-gate ISFET $\mathrm{pH}$ sensor. Journal of Materials Science: Materials in Electronics, 30(7), 71637174.

Syu, M. J., \& Chang, Y. S. (2009). Ionic effect investigation of a potentiometric sensor for urea and surface morphology observation of entrapped urease/polypyrrole matrix. Biosensors and Bioelectronics, 24(8), 2671-2677.

Şen, M., \& Demirci, A. (2016). pH-dependent ionic-currentrectification in nanopipettes modified with glutaraldehyde cross-linked protein membranes. RSC advances, 6(89), 86334-86339.

Şen, M., Ino, K., Inoue, K. Y., Suda, A., Kunikata, R., Matsudaira, M., Shiku, H. \& Matsue, T. (2014). Electrochemical evaluation of sarcomeric $\alpha$-actinin in embryoid bodies after gene silencing using an LSI-based amperometric sensor array. Analytical Methods, 6(16), 6337-6342.

Şen, M., Ino, K., Ramón-Azcón, J., Shiku, H., \& Matsue, T. (2013a). Cell pairing using a dielectrophoresis-based device with interdigitated array electrodes. Lab on a Chip, 13(18), 3650-3652.

Şen, M., Ino, K., Shiku, H., \& Matsue, T. (2012). Accumulation and detection of secreted proteins from single cells for reporter gene assays using a local redox cycling-based electrochemical (LRC-EC) chip device. Lab on a Chip, $12(21), 4328-4335$.

Vonau, W., \& Guth, U. (2006). pH monitoring: a review. Journal of Solid State Electrochemistry, 10(9), 746-752.

Yun, D. H., Song, M. J., Sim, H., \& Hong, S. I. (2006, October). Sensitivity improvement of polypyrrole-based urea sensor using copper ion doping effect. In 2006 IEEE Nanotechnology Materials and Devices Conference (Vol. 1, pp. 574-575). IEEE 